\section{Re: Fysisk aktivitet, røyking og dødelighet hos menn som deltok i Oslo-undersøkelsene i 1972 og 2000}

Det er velkjent at nivå av fysisk aktivitet er forbundet med dødelighet, men det er få norske longitudinelle studier av denne sammenhengen. Holme \& Anderssens studie (1) bekrefter at det er en dose-respons-sammenheng mellom fysisk aktivitet og dødelighet også blant norske menn.

I en artikkel publisert i 2012 (2) viste vi forskjeller og likheter i sammenhengen mellom fysisk aktivitet og generell dødelighet, slagdødelighet og død som følge av iskemisk hjertesykdom i ulike aldersgrupper hos norske kvinner og menn. 5653 tilfeldig utvalgte menn og kvinner i alderen 20-79 og bosatt i Bergen i 1964 deltok i en utvidet helseundersøkelse der både kliniske og selvrapporterte variabler ble registrert. 788 av deltakerne var $\geq 65$ år. Datamaterialet ble koblet mot Levekårsundersøkelsene i 1970-80-90 og 2000, Dødsårsaksregisteret (2005) og Folkeregisteret (2007). Vi benyttet Cox-regresjon og beregnet tilskrivbar risiko for å kunne sammenlikne betydningen av fysisk inaktivitet og andre risikofaktorer (blant andre røyking) for dødelighet.

Mens de fleste andre kjente risikofaktorer har avtakende betydning for dødelighet med økende alder, fant vi at sammenhengen mellom fysisk aktivitet og overlevelse var minst like sterk hos eldre som hos yngre. $9 \%$ av dødsfallene kunne tilskrives mangel på fysisk aktivitet. Resultatene fra Holme \& Anderssens studie peker i samme retning: Fysisk aktivitet har minst like stor betydning som røyking, og fysisk aktivitet er forbundet med redusert dødelighet, også blant eldre. Fysisk aktivitet har betydelige implikasjoner for overlevelse i alle aldersgrupper. I tillegg kan fysisk aktivitet øke bentetthet, muskelvolum og -styrke, bedre gangfunksjon og redusere risiko for fall og frakturer, bidra til mindre hjelpebehov og en mer uavhengig og selvstendig alderdom (3).

Mer enn 600 menn og kvinner $\geq 65$ år ble i 2009-10 inkludert i Birkebeiner aldringsstudien. Oppfølging av disse «verdens sprekeste eldre» vil forhåpentligvis gi oss mer kunnskap om sammenhenger mellom fysisk aktivitet og funksjonsevne i høy alder. I mellomtiden fortsetter vi å oppfordre eldre til å være aktive. Det er aldri for sent å starte med fysisk aktivitet, effektene inntrer raskt og det innebærer forsvinnende få uheldige bivirkninger.

\section{Anne K. Gulsvik \\ annekristine.gulsvik@diakonsyk.no \\ Marius Myrstad \\ Dag S. Thelle}

Anne K. Gulsvik (f. 1972) er overlege ved Diakonhjemmet sykehus. Ingen oppgitte interessekonflikter.

Marius Myrstad (f. 1978) er lege i spesialisering og stipendiat ved Diakonhjemmet sykehus.

Ingen oppgitte interessekonflikter.

Dag S. Thelle (f.1941) er professor emeritus (epidemiologi) ved avd. for biostatistikk, Universitetet i Oslo.

Ingen oppgitte interessekonflikter.

\section{Litteratur}

1. Holme I, Anderssen SA. Fysisk aktivitet, røyking og dødelighet hos menn som deltok i Oslo-undersøkelsene i 1972 og 2000. Tidsskr Nor Legeforen 2014; 134 $1743-8$.

2. Gulsvik AK, Thelle DS, Samuelsen SO et al. Ageing, physical activity and mortality-a 42-year follow-up study. Int J Epidemiol 2012; 41: 521-30.

3. Chodzko-Zajko WJP. Proctor DNP. Fiatarone Singh MAM et al; American College of Sports Medicine. American College of Sports Medicine position stand. Exercise and physical activity for older adults. Med Sci Sports Exerc 2009; 41 : $1510-30$

\section{Re: Et korstog mot legemiddelindustrien}

I Tidsskrift for den norske legeforening nr. 19/2014 har Steinar Madsen fra Legemiddelverket anmeldt Peter C. Gøtzsches bok Deadly Medicines and Organised Crime - How big pharma has corrupted healthcare, utgitt av Radcliffe Publishing (2013) (1).

Selv om det er aldri så uakseptabelt, er det kanskje forståelig at det har vært fristende for legemiddelindustrien å tøye grenser for å tjene enda mer penger. Det er derimot langt mer betenkelig at de kontrollrutiner samfunnet har, de som skal hindre at vi som samfunn og individer blir skadet av industrien på den måte Gøtzsche beskriver i sin bok, åpenbart ikke har gjort jobben sin godt nok. Dette synes å være den mest alvorlige kritikken i Gøtzsche sin bok, slik jeg har lest den. Rent prinsipielt virker det derfor merkelig at Tidsskriftet har latt en som åpenbart rammes av denne kritikken selv anmelde boken. Som representant for Legemiddelverket må Madsen gjerne gå påstandene $\mathrm{i}$ boken i møte, fortrinnsvis $\mathrm{i}$ et debattinnlegg. Men er han inhabil i forhold til å anmelde boken?

Når det gjelder selve anmeldelsen synes det som om Madsen går langt $\mathrm{i}$ å forsøke å latterliggjøre en del av innholdet $\mathrm{i}$ boken. Påståtte unøyaktigheter og svakheter i boken omtales i generelle vendinger uten å komme med eksempler. Jeg har selv nylig lest boken, og synes den er både velskrevet, skremmende og troverdig (selv om jeg ikke har nok kunnskap til å kunne gå god for alt som står der, og jeg har heller ikke lest noen av de 900 referansene). Gøtzsche selv skriver at målet aldri var å gi en balansert fremstilling av legemiddelindustriens rolle i samfunnet, men å dokumentere de mindre heldige sidene ved industrien og de skadene den har påført samfunnet.

Uansett om man flisespikker på detaljer; basert på det omfattende materialet Gøtzsche viser til virker det som hevet over enhver rimelig tvil at industrien har drevet med både svindel og korrupsjon. Legemiddelindustrien har vel ikke blitt ilagt bøter på mer enn 10 milliarder dollar de senere årene uten grunn?

\section{Rune Johansen}

Rune.Johansen@fhi.no

Rune Johansen (f. 1962) er forsker ved Folkehelseinstituttet Ingen oppgitte interessekonflikter.

\section{Litteratur \\ 1. Madsen S. Et korstog mot legemiddelindustrien. Tidsskr Nor Legeforen 2014 134: 1869 .}

\section{Re: Et korstog mot legemiddelindustrien}

Steinar Madsens anmeldelse af min bog i Tidsskriftet nr. 19/2014 (1) er fagligt set ikke i orden. Jeg mistænker, at hans emotionelle angreb på min bog hænger sammen med, at han har arbejdet næsten 20 år ved Legemiddelverket. Jeg kritiserer jo vore lægemiddelmyndigheder ganske skarpt i bogen og dokumenterer, at der både findes interessekonflikter og korruption. Madsen taler med samme stemme som medicinalindustrien, der i Danmark - ligesom Madsen også gør - har betegnet min bog som et korstog mod industrien. Det er et retorisk kneb, som får min mission til at se mindre seriøs ud.

Madsens boganmeldelse er fuld af tarvelige antydninger om, at det nok ikke er helt rigtigt, hvad jeg skriver i bogen. Han giver ikke et eneste eksempel, og jeg tror heller ikke, han kan finde noget, for så vidt jeg ved, er alt, hvad jeg skriver korrekt. På ganske samme måde har Lægemiddelindustriforeningen i Danmark forsøgt at nedgøre min bog. Værst af alt kalder Madsen det for overdrivelser, når jeg bruger ord som «corruption» og «fraud». Det er det da ikke, jeg kalder bare en spade for en spade, i modsætning til Madsen. Min bog har over 900 referencer, og jeg dokumenter, at korruption, svindel og bedrag er så udbredt, at det, de store firmaer foretager sig, opfylder kriterierne i amerikansk lov for organiseret kriminalitet.

Madsen er ikke udelukkende negativ og medgiver endda, at han 